\title{
Antecedents of revisited intention : Evidence from Indonesia zoo tourism
}

\author{
Antecedentes de intención revisada: evidencia del turismo del \\ zoológico de Indonesia
}

Jasanta Peranginangin*

Institut Agama Islam Negeri Surakarta, Indonesia

Received 24 May 2017; accepted 22 January 2017

Available online 4 December 2018

\begin{abstract}
This study aimed to find out antecedences that affected revisited intention to the zoo. Opportunities to developing tourism industry especially in zoo tourism management. This study applied a quantitative research method using 200 questionaires disseminated to zoo tourists, in which 166 of these were completed. The study applied a structured equation modeling (SEM) with Partial Least Squere. Results of the study revealed important factors to build revisited intention to the zoo. This study found that all variables are significant affecting to revisited intention. This study will strengtened the previous research about revisited intention to zoo tourism. This research finding provides conceptual framework revisited intention. All of variables relationship proved the same result as previous studies about service quality, image, satisfaction and revisit intention. The proposed model tested empirically, the model shown that all variables is an ideal strategy to built zoo tourism competitiveness. This study reveals the antecedents of the desire to revisit the zoo, this is very important given the lack of research on the sustainability of a zoo. This study will contributed to the body of knowledge.
\end{abstract}

JEL codes: $\mathrm{L} 83, \mathrm{M} 31, \mathrm{Z} 32$

Keywords: Revisited intention; Tourist satisfaction; Service quality; Zoo image.

\footnotetext{
*Corresponding author.

E-mail address: jasanta.pa@gmail.com

Peer Review under the responsibility of Universidad Nacional Autónoma de México.
} 


\section{Resumen}

Este estudio tuvo como objetivo descubrir los antecedentes que afectaron la intención revisada del zoológico. Oportunidades para desarrollar la industria del turismo, especialmente en la gestión del turismo zoológico. Este estudio aplicó un método de investigación cuantitativa utilizando 200 cuestionarios diseminados a los turistas del zoológico, en los cuales se completaron 166 de estos. El estudio aplicó un modelo de ecuaciones estructurado (SEM) con Partial Least Squere. Los resultados del estudio revelaron factores importantes para construir una nueva intención para el zoológico. Este estudio encontró que todas las variables son significativas y afectan la intención revisada. Este estudio reforzará la investigación previa sobre la intención revisada del turismo zoológico. Este hallazgo de investigación proporciona una intención revisada del marco conceptual. Todas las relaciones de variables demostraron el mismo resultado que los estudios previos sobre la calidad del servicio, la imagen, la satisfacción y la intención de revisar. El modelo propuesto probado empíricamente, el modelo mostró que todas las variables son una estrategia ideal para construir la competitividad del turismo zoológico. Este estudio revela los antecedentes del deseo de volver a visitar el zoológico, esto es muy importante dada la falta de investigación sobre la sostenibilidad de un zoológico. Este estudio contribuirá al cuerpo de conocimiento.

Códigos JEL: L83, M31, Z32

Palabras clave: Intención revisada; Satisfacción del turista, Calidad del servicio; Imagen del zoológico.

\section{Introduction}

Tourism is a key driver highly dinamic socio-economic growth Najda-Janoszka and Kopera (2014). Zoo as a product of tourism industry increases the economic growth. Zoo visitors has significance contribution to amount of tourism industry development. Creating zoo as a favorite destination makes this research note worthy.

Zoo as one of favorite destinations generates empowering society environment and has multiple effect on the economy. Other businesses will grow around the zoo environment. Revisit intention becomes a fundamental aspect in depeloving economic sphere. Strategic development tourism is about linking different markets to different tourist products (Korunovski \& Marinoski, 2012).

Service quality and destination image are the first pivotal points to understand tourist satisfaction then to create repeat visitation Hui, Wan, and Cheng (2010). Service quality and image are the prime factors to built satisfaction (Peranginangin, 2009).This study was composed to prove; a) the effect of service quality on tourist satisfaction; b) the effect of service quality on revisited intention; c) the effect of zoo image on tourist satisfaction; d) the effect of zoo image on revisited intention; and e) the effect of tourist satisfaction on revisited intention. This research is divided into 5 sections, the first is the introduction, then the second part is the literature review, the third part is the research methodology, the fourth part is the research methodology, and the last part is the conclusion and the research implications

\section{Literature review}

Destination generating by five components are infrastucture, empowering public service, destination image, environment, and the perfect system among the destination(Ting, Ru-liang, 
\& Xiao-juan, 2011). Service quality and destination image become pivotal to strengthen tourist satisfaction and revisited intention to the destination. The favorable destination depends on tourist revisited intention ti raise their expenditure.

A study (Byon \& Zhang, 2010) explains that image destination as measurement sticks to determine visitors satisfaction. Destination image in order to predicted tourist revisit intention, and recommended to others. Therefore, destination image affects the tourists revisit intention significantly.

Service quality and destination image are two important variables to build visitors satisfaction to the destination. Tourists satisfaction will affect to revisited. Another study (Guntoro \& Hui, 2013) concludes that satisfaction to price competitiveness, quality, variety, and better service in order to increase tourist satisfaction. Tourists satisfaction is an affecting factor to repeat visitation to the destination.

\section{Service quality and satisfaction relationship}

Dominici and Guzzo (2010) found that service quality affects visitors satisfaction. A research of Supitchayangkool (2012) concludes that service quality significantly affects the visitors satisfaction and tourists revisited intention. Fulfilling specific needs of visitors becomes the prime factors to raise visitors satisfaction and revisited intention (Gina Ionela Butnarua \& Miller, 2012; Quintal and Polczynski (2010)).

Gina Ionela Butnarua and Miller (2012) describe that service quality leads to visitors satisfaction, the nature of service quality is about reaching the tourist satisfaction, personnel's satisfaction, and the objective of organitation. The study on satisfaction (Araslı \& Baradarani, 2014) found service quality in lodging, atrraction, shopping, safety, and transportation has stong effect to tourist satisfaction. Felix (2017) concluded that service quality would have a significant impact on increasing satisfaction.

The above description led this study to proposing the following hypothesis:

H1 : The higher degree of service quality, the higher degree of Visitors satisfaction.

\section{Service quality and revisited intention relationship}

Service quality is built as personal touch to each visitors, giving personal service to visitors through standardised service quality. Alegre and Cladera (2009) found that service quality and quantity of previous visits have significant effect on revisit intention. Bigne, 'nchez, and Andreu (2009) explain that tourist satisfaction is the most relevant factor to short and long term revisit intention.

Service quality effecting positevely to visitors revisited intention (Hsieh, 2012). Similarly, the higher degree of service quality will effect to the higher degree of visitors revisit intention (Yang, Wang, Huang, \& Chang, 2010), (Quintal \& Polczynski, 2010). 
Therefore, the study proposed the following hypothesis:

$\mathrm{H} 2$ : The higher degree of service quality, the higher degree of revisited intention.

\section{Zoo image and tourist satisfaction relationship}

Pratminingsih, Rudatin, and Rimenta (2014) found that destination image affects significantly the tourists satisfaction. The higher degree of destination image will increase the tourists visiting to the destination. Another study (Kuo, Chang, \& Huang, 2014) describes destination image relationship with tourist satisfaction and revisit intention.

Ryu, Lee, and Kim (2012) conclude that image strongly affects the tourist satisfaction. Image is divided into distinctiveness of stereotypical image, distinctiveness of affective image, and distinctiveness uniqueness image (Pan \& Li, 2011). Research conducted Melo, Moniz, Silva, and Batista (2017) also proved as a tourist spot image is very aligned to the satisfaction of visitors. Image affective to the tourist satisfacion, the higher degree of image then then the higher degree of tourist satisfaction.

Therefore, the study proposed the following hypothesis:

H3 : The higher degree of zoo image, the higher degree of tourists satisfaction.

\section{Zoo image and revisited intention relationship}

Greaves and Skinner (2010), (Byon \& Zhang, 2010) describe destination image effecting significantly to revisited intention. Research finding of Som, Marzuki, Yousefi, and AbuKhalifeh (2012), (Pratminingsih et al., 2014)concluded that destination image have strong relationship to revisited intention.

Mohamad, Abdullah, and Mokhlis (2012), Som et al. (2012) found that factors affecting the revisited intention are a good destination image, modern environment, pleasant, hospitality, and beautiful places to enjoy. There is a positive correlation between destination image to tourists revisited intention (Lertputtarak, 2012) explained. Artuger and Cetinsoz (2017) explains that the image of the zoo influences the desire of tourists revisited. Image consists of two types of cognitive image and affective image

Therefore, the study proposed the following hypothesis:

$\mathrm{H} 4$ : The higher degree of zoo image, the higher degree of revisited intention

\section{Tourist satisfaction and revisited intention relationship}

Kim, Kim, and Taylor (2010) explain revisit intention to the destination measurement by visitors satisfaction. (Quintal \& Polczynski, 2010) [Quintal and Polczynski (2010)] also 
describe that good governance of destination will cause an increase in visitors satisfaction and, in turn, will affect the revisit intention. The effect of competition on visitors satisfaction will result in loyalty to the destination (Taplin, 2013).

Raza, Siddiquei, Awan, and Bukhari (2012) discover that visitors satisfaction have positive relationship to tourists revisited intention. The similar study (Supitchayangkool, 2012) found that visitors satisfaction have positive relationship to revisited intention. Furthermore, tourist satisfaction as a significant trigger of revisited intention (Marinkovic, Senic, Ivkov, Dimitrovski, \& Bjelic, 2014)

Therefore, the study proposed the hypothesis:

H5 : The higher degree of tourist satisfaction, the higher degree of revisited intention

Figure 1

The Proposed Model

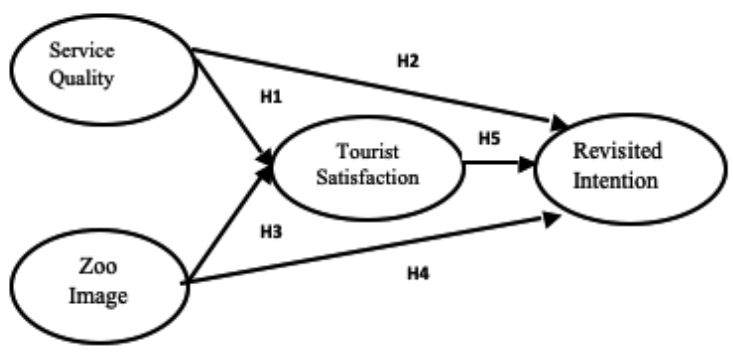

\section{Research methodology}

This study was conducted on zoo visitors in a Special Province of Jogjakarta, Indonesia. Where this area is the second largest international tourist destination in Indonesia after Bali. Zoo visitors who become the target of research are local tourists and foreign tourists. This research is very interesting because there are 68 zoos in Indonesia and more than 50 million per year zoo visitors in Indonesia.

This research applies the structural equations of modelling, in SEM sample size depends on the complexity of a research model. The number of sample participants required is five times the number of observed parameters, the number of parameters in this study amounted to 33, so that the minimum participants to be surveyed by 165 respondents, (Bentler \& Chou, 1987). The research model using the construct $\leq 5$ minimum sample size required is 100 respondents, (Joseph F Hair, Black, Babin, \& Anderson, 2014).

This research methodelogy examined structured equation modeling with partial least squares (Kock, 2011), (J.F Hair, Ringle, \& Sarstedt, 2013). The correlation between five hyphotheses measured five variables correlation measured using fourten indicators. Questionnaires were disseminated to 200 respondents who just came out of the zoo. There were 166 questionnaires or 
$83 \%$ of the total, that could be processed figuring the population. The data collected structured equation modeling conditions, Tabachnick and Fidell (2007) and Joseph F. Hair, Black, Babin, and Anderson (2010). These questionnaires consisted of opened and closed questions. Closed questionnaire 1-10 scale abridge to respondents answering. The opened questions were used for completing uncovered answer of closed questions.

\section{Results}

All of the variables were tested using WarpPLS, the hypotesized model fit, as evidenced shown below :

Table 1

Model Fit Indices and P Values

\begin{tabular}{ll}
\hline $\mathrm{APC}=0.341$ & $\mathrm{P}<0.001$ \\
$\mathrm{ARS}=0.632$ & $\mathrm{P}<0.001$ \\
$\mathrm{AVIF}=2.154$ & Good if $<5$ \\
\hline
\end{tabular}

Table 1 shows that $\mathrm{P}$ values of Average Path Coefficient (APC) and Average R-Squared (ARS) $<0.05$, so that Average Variance Inflation Factor (AVIF) result 2.154, good if $<5$.

Table 2

Standard Errors for path coefficients

\begin{tabular}{lllll}
\hline & SQ & ZI & TS & RI \\
\hline SQ & & & & \\
ZI & & & & \\
TS & 0.101 & 0.097 & & \\
RI & 0.104 & 0.089 & 0.101 &
\end{tabular}

Table 2 shows result of standard error for part coefficients Service Quality (SQ) to Tourist Satisfaction (TS) 0.101, Zoo Image (ZI) to Tourist satisfaction (TS) 0.097, Service Quality to Revisit Intention (RI) 0.104, Zoo Image (ZI) to Revisit intention 0.089, and Tourist Satisfaction to Revisi Intention 0.101. 
Table 3

Effect sizes for path coefficients

\begin{tabular}{lllll}
\hline & SQ & ZI & TS & RI \\
\hline SQ & & & & \\
ZI & & & & \\
TS & 0.104 & 0.571 & & \\
RI & 0.05 & 0.177 & 0.361
\end{tabular}

Table 3 shows the result of effect sizes for path coefficients, score for Service Quality (SQ) to Tourist Satisfaction (TS) 0.104 , Zoo Image (ZI) to Tourist satisfaction (TS) 0.571 , Service Quality (SQ) to Revisit Intention (RI) 0.05 , Zoo Image (ZI) to Revisit intention (RI) 0.177, and Tourist Satisfaction to Revisi Intention 0.361.

Table 4

Correlation Among Indicators

\begin{tabular}{|c|c|c|c|c|c|c|c|c|c|c|c|}
\hline & SQ1 & SQ2 & SQ3 & SQ4 & SQ5 & ZI1 & $\mathrm{ZI} 2$ & $\mathrm{ZI} 3$ & TS1 & TS2 & TS3 \\
\hline SQ1 & 1 & 0.45 & 0.45 & 0.32 & 0.23 & 0.41 & 0.34 & 0.35 & 0.42 & 0.42 & 0.42 \\
\hline SQ2 & 0.45 & 1 & 0.42 & 0.29 & 0.26 & 0.25 & 0.22 & 0.32 & 0.3 & 0.3 & 0.22 \\
\hline SQ3 & 0.45 & 0.42 & 1 & 0.51 & 0.41 & 0.41 & 0.48 & 0.43 & 0.4 & 0.48 & 0.4 \\
\hline SQ4 & 0.32 & 0.29 & 0.51 & 1 & 0.36 & 0.23 & 0.36 & 0.41 & 0.29 & 0.31 & 0.29 \\
\hline SQ5 & 0.23 & 0.26 & 0.41 & 0.36 & 1 & 0.26 & 0.38 & 0.56 & 0.44 & 0.39 & 0.38 \\
\hline ZI1 & 0.41 & 0.25 & 0.41 & 0.23 & 0.26 & 1 & 0.48 & 0.41 & 0.45 & 0.56 & 0.51 \\
\hline $\mathrm{ZI} 2$ & 0.34 & 0.22 & 0.48 & 0.36 & 0.38 & 0.48 & 1 & 0.6 & 0.59 & 0.55 & 0.6 \\
\hline $\mathrm{ZI} 3$ & 0.35 & 0.32 & 0.43 & 0.41 & 0.56 & 0.41 & 0.6 & 1 & 0.66 & 0.61 & 0.63 \\
\hline TS1 & 0.42 & 0.3 & 0.4 & 0.29 & 0.44 & 0.45 & 0.59 & 0.66 & 1 & 0.66 & 0.69 \\
\hline $\mathrm{TS} 2$ & 0.42 & 0.3 & 0.48 & 0.31 & 0.39 & 0.56 & 0.55 & 0.61 & 0.66 & 1 & 0.62 \\
\hline $\mathrm{TS} 3$ & 0.42 & 0.22 & 0.4 & 0.29 & 0.38 & 0.51 & 0.6 & 0.63 & 0.69 & 0.62 & 1 \\
\hline RI1 & 0.38 & 0.24 & 0.37 & 0.21 & 0.39 & 0.45 & 0.53 & 0.55 & 0.57 & 0.52 & 0.6 \\
\hline RI2 & 0.44 & 0.23 & 0.49 & 0.27 & 0.45 & 0.48 & 0.56 & 0.57 & 0.6 & 0.55 & 0.68 \\
\hline RI3 & 0.41 & 0.25 & 0.39 & 0.28 & 0.34 & 0.42 & 0.56 & 0.53 & 0.55 & 0.52 & 0.69 \\
\hline
\end{tabular}

Table 4 shows scores of correlation among indicators described good correlationamong indicators with diagonal scores 1 . 
Table 5

Latent Variables Coefficients

\begin{tabular}{lllll}
\hline & SQ & ZI & TS & RI \\
\hline R-squared & & & 0.675 & 0.589 \\
Composite Realib. & 0.832 & 0.857 & 0.909 & 0.94 \\
Cronbach's alpha & 0.746 & 0.748 & 0.85 & 0.904 \\
Avg.var.extrac. & 0.499 & 0.666 & 0.77 & 0.84 \\
Full collin. Vif & 1.725 & 3.257 & 3.375 & 2.312 \\
Q-squared & & & 0.682 & 0.591
\end{tabular}

Table 5 describes all variables significantly affected above 50\%. R-squared for tourist satisfaction $67,5 \%$ and Revisit Intention $58,9 \%$ it means that all variables were standadized.

Table 6

Latent Variables Correlation

\begin{tabular}{lllll}
\hline & SQ & ZI & TS & RI \\
\hline SQ & $(0.706)$ & 0.626 & 0.588 & 0.531 \\
ZI & 0.626 & $(0.816)$ & 0.8 & 0.691 \\
TS & 0.588 & 0.8 & $(0.877)$ & 0.728 \\
RI & 0.531 & 0.691 & 0.728 & $(0.916)$
\end{tabular}

Note : Average Variances Extracted shown on diagonal

Table 6 shows diagonal scores above $0.7(0.706,0.816,0.877$, and 0.916$)$. It meant that there were no difficulties to respondent answering the quationaires. All questionaires possessed good quality.

Table 7

$\mathrm{P}$ Value for Correlations

\begin{tabular}{lllll}
\hline & SQ & ZI & TS & RI \\
\hline SQ & 1 & $<0.001$ & $<0.001$ & $<0.001$ \\
ZI & $<0.001$ & 1 & $<0.001$ & $<0.001$ \\
TS & $<0.001$ & $<0.001$ & 1 & $<0.001$ \\
RI & $<0.001$ & $<0.001$ & $<0.001$ & 1
\end{tabular}

Table 7 shows all variables had $\mathrm{P}$ Value $<0.001$. It meant that all variables were reliable to this research. 


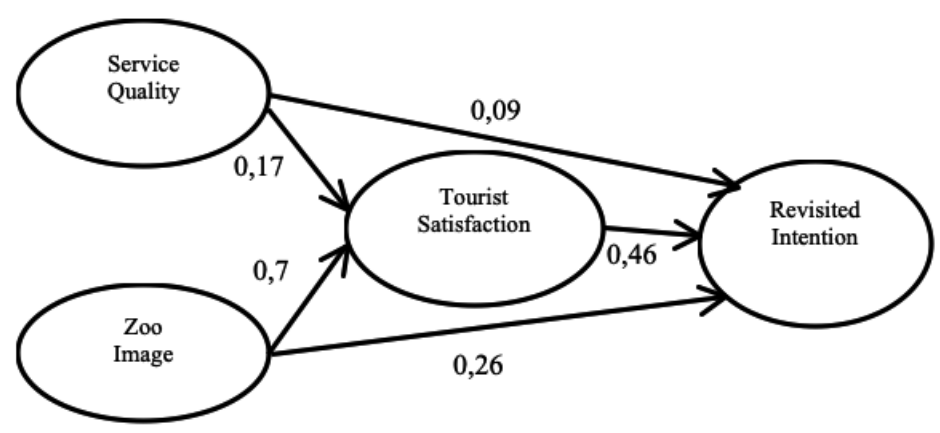

Figure 2

The Result of Proposed Model

Figure 2 shows the result of proposed model revisit intention with mediating tourist satisfaction. The correlation of service quality to tourist satisfaction of 0.17 was significant. It meant that hypothesis 1 was proved. Hypothesis 2 the higher degree of service quality, the higher degree of revisit intention was significant at 0.09 . The correlation of zoo image to tourist satisfaction was strongly significant. Therefore, Hypothesis 3 was proved. Hypothesis 4 , the higher degree of zoo image, the higher degree of revisited intention proved at 0.26 . Hypothesis 5 , strength relationship tourist satisfaction with revisited intention of 0.46 . All hypotheses were proven significant to built revisited intention in zoo tourism.

The correlation among all variables drew an inference that zoo image (0.7) had a stronger effect than service quality connection to tourist satisfaction. The revisited intention effect of zoo image $(0.26)$ had a stronger effect than service quality 0.09 . the tourist satisfaction have significant effect to the revisited intention. The wishes of a revisit intention can be directly influenced by the image of the zoo and the quality of service or through mediation of tourist satisfaction. According to the result, focusing in service quality improvement.

\section{Conclusions}

This research finding provides conceptual framework revisited intention.All of variables relationship have proven the same result as the previous studies on service quality, image, satisfaction and revisit intention. The proposed model tested empirically, the model shown that all variables is an ideal strategy to built zoo tourism competitiveness.

The result of this research contributes to marketing theory and managerial policy to enhanced zoo performance.Improving service quality, zoo image, and tourist satisfaction will makes all tourist more comportable to repeat their visitation. Managerial focusing on tourist satisfaction through service quality especially animal atrraction and supporting environment around zoo.

This study had the following limitations: firstly, this research only focused on zoo visitors without exlore the demograpic and social economic of the population; secondly, the respondents were only the visitors just come out from the zoo. This study requires future research to build 
a stronger model. The indicators and population of the research object must beenlarge, so the variables added to make the model more powerful. Only few studies had been performed about the zoo tourism. Therefore, this research is attractive to developed.

\section{References}

Alegre, J. n., \& Cladera, M. (2009). Analyzing The Effect of Satisfaction and Previous Visits on Tourist Intentions to Return. European Journal of Marketing, Vol. 43 No. 5/6, PP. 670-685. https://doi.org/10.1108/03090560910946990

Arasl1, H., \& Baradarani, S. (2014). European Tourist Perspective on Destination Satisfaction in Jordan's industries. Social and Behavioral Sciences, Volume 109. https://doi.org/10.1016/j.sbspro.2013.12.645

Artuger, S., \& Cetinsoz, B. C. (2017). The Impact of Destination Image and The Intention to Revisit: A Study Regarding Arab Tourists. Europian Scientific Journal, Volume 13, No. 5. https://doi.org/10.19044/esj.2017.v13n5p82

Bentler, P. M., \& Chou, C. P. (1987). Practical Issues in Structural Modeling. Sociological Methods and Research, Volume: 16, Issue: 1, Page(s): 78-117. https://doi.org/10.1177/0049124187016001004

Bigne, J. E., 'nchez, I. S., \& Andreu, L. (2009). The Role of Variety Seeking in Short and Long Run Revisit Intentions in Holiday Destinations. International Journal of Culture, Tourism, and Hospitality Research, VOL. 3 NO. 2, PP. 103-115. https://doi.org/10.1108/17506180910962113

Byon, K. K., \& Zhang, J. J. (2010). Development of A Scale Measuring Destination Image. Marketing Intelligence \& Planning, Vol. 28 No. 4, PP. 508-532. https://doi.org/10.1108/02634501011053595

Dominici, G., \& Guzzo, R. (2010). Customer Satisfaction in the Hotel Industry: A Case Study from Sicily. International Journal of Marketing Studies, Vol. 2, No. 2. https://doi.org/10.5539/ijms.v2n2p3

Felix, R. (2017). Service Quality and Customer Satisfaction in Selected Banks in Rwanda. Journal of Business and Financial Affairs, Volume 6(Issue 1). https://doi.org/10.4172/2167-0234.1000246

Gina Ionela Butnarua, \& Miller, A. (2012). Conceptual Approaches On Quality and Theory of Tourism Services Procedia Economics and Finance, Volume 3. https://doi.org/10.1016/s2212-5671(12)00167-0

Greaves, N., \& Skinner, H. (2010). The Importance of Destination Image Analysis to UK Rural Tourism. Marketing Intelligence \& Planning, Vol. 28 No. 4, PP. 486-507. https://doi.org/10.1108/02634501011053586

Guntoro, B., \& Hui, T. K. (2013). Travel Satisfaction and Revisit Intention of Chinese Visitors: The Case of Singapore Advances in Hospitality and Leisure, Volume 9, pp. 29-47. https://doi.org/10.1108/s1745-3542(2013)0000009006

Hair, J. F., Black, W. C., Babin, B. J., \& Anderson, R. E. (2014). Multivariate Data Analysis (S. Edition Ed.). United State of America: Pearson Education Limited.

Hair, J. F., Ringle, C. M., \& Sarstedt, M. (2013). Partial Least Squares Structural Equation Modeling: Sagepub.

Hsieh, W.-C. (2012). A Study of Tourists on Attraction, Service Quality, Perceived Value and Behavioral Intention in the Penghu Ocean Firework Festival The Journal of International Management Studies, Volume 7 Number 2. https://doi.org/10.9734/ajeba/2017/38899

Hui, T. K., Wan, D., \& Cheng, H. Y. (2010). Case Study of Tourist Revisit Behavior in Singapore. Advances in Hospitality and Leisure, Volume 6, 27-42. https://doi.org/10.1108/s1745-3542(2010)0000006006

Joseph F. Hair, J., Black, W. C., Babin, B. J., \& Anderson, R. E. (2010). Multivariate Data Analysis (Vol. Seventh Edition). United State of America: Pearson Prentice Hall.

Kim, Y.H., Kim, M., \& Taylor, T. R. a. J. (2010). An Examination of Festival Attendees'Behavior Using SEM. International Journal of Event and Festival Management, Vol.1 No.1, PP.86-95. https://doi.org/10.1108/17852951011029324

Kock, N. (2011). Using WarpPLS in e-Collaboration Studies: Mediating Effect, Control, and Second Order Variables and Algorithm Choices. International Journal of e-Collaboration. https://doi.org/10.4018/jec.2011070101

Korunovski, S., \& Marinoski, N. (2012). Cultural Tourism In Ohrid As A Selective Form of Tourism Development Social and Behavioral Sciences, Volume 44., 104-113 https://doi.org/10.1016/j.sbspro.2012.05.010

Kuo, N.-T., Chang, K.-C., \& Huang, H.-H. (2014). The Effect of Destination Image on Tourist Loyalty in Kinmen Battlefield Tourism: The Mediating Role of Tourist Satisfaction and the Moderating Roles of Tour Guide Interpretation Performance and Perceived Value The Journal of American Academy of Business, Cambridge, Vol. 20. 
Lertputtarak, S. (2012). The Relationship between Destination Image, Food Image, and Revisiting Pattaya, Thailand. International Journal of Business and Management, Vol. 7, No. 5. https://doi.org/10.5539/ijbm.v7n5p111

Marinkovic, V., Senic, V., Ivkov, D., Dimitrovski, D., \& Bjelic, M. (2014). The Antecedents of Satisfaction and Revisit Intentions For Full Service Restaurants. Marketing Intelligence \& Planning, Volume 32 No. 3, pp. 311-327. https://doi.org/10.1108/mip-01-2013-0017

Melo, H. M. P., Moniz, A. I., Silva, F. J. F., \& Batista, M. D. G. (2017). Tourist Destination Image and Consumer Behaviour: The Case of Azores. Journal of Spatial and Organizatinal Dynamics, Volume V(Issue 2), 73-82. https:// doi.org/10.1079/9781845937942.0083

Mohamad, M., Abdullah, A. R., \& Mokhlis, S. (2012). Tourists' Evaluations of Destination Image and Future Behavioural Intention: The Case of Malaysia Journal of Management and Sustainability, Vol. 2, No. 1. https://doi. org/10.5539/jms.v2n1p181

Najda-Janoszka, M., \& Kopera, S. (2014). Exploring Barriers To Innovation In Tourism Industry - The Case of Southern Region of Poland. Social and Behavioral Sciences, Volume 110., 190 - 201. https://doi.org/10.1016/j. sbspro.2013.12.862

Pan, B., \& Li, X. R. (2011). The Long Tail of Destination Image and Online Marketing. Annals of Tourism Research, Volume 38, No. 1, pp. 132-152. https://doi.org/10.1016/j.annals.2010.06.004

Peranginangin, J. (2009). Studi Peningkatan Loyalitas Pelanggan Ritel. Diponegoro University, Semarang.

Pratminingsih, S. A., Rudatin, C. L., \& Rimenta, T. (2014). Roles of Motivation and Destination Image in Predicting Tourist Revisit Intention: A Case of Bandung - Indonesia. International Journal of Innovation, Management and Technology, Vol. 5, No. 1. https://doi.org/10.7763/ijimt.2014.v5.479

Quintal, V. A., \& Polczynski, A. (2010). Factors Influencing Tourists' Revisit Intentions. Asia Pacific Journal of Marketing and Logistics, Vol. 22 No. 4, PP. 554-578. https://doi.org/10.1108/13555851011090565

Raza, M. A., Siddiquei, A. N., Awan, P. D. H. M., \& Bukhari, K. (2012). Relationship Between Service Quality, Perceived Value, Satisfaction, and Revisit Intention in Hotel Industry. Institute of Interdisciplinary Business Research, VOL 4, NO 8 .

Ryu, K., Lee, H. R., \& Kim, W. G. (2012). The Influence of The Quality of The Physical Environment, Food, and Service on Restaurant Image, Customer Perceived Value, Customer Satisfaction, and Behavioral Intentions. International Journal of Contemporary Hospitality Management Decision, Volume 24 No. 2, pp. 200-223. https://doi. org/10.1108/09596111211206141

Som, A. P. M., Marzuki, A., Yousefi, M., \& AbuKhalifeh, A. a. N. (2012). Factors Influencing Visitors' Revisit Behavioral Intentions: A Case Study of Sabah, Malaysia International Journal of Marketing Studies, Vol. 4, No. 4. https://doi.org/10.5539/ijms.v4n4p39

Supitchayangkool, S. (2012). The Differences between Satisfied/Dissatisfied Tourists towards Service Quality and Revisiting Pattaya, Thailand International Journal of Business and Management, Vol. 7, No. 6. https://doi. org/10.5539/ijbm.v7n6p30

Tabachnick, B. G., \& Fidell, L. S. (2007). Using Multivariate Statistics (Vol. Fifth Edition). United State of America: Person.

Taplin, R. H. (2013). The Influence of Competition on Visitor Satisfaction and Loyalty. Tourism Management, Volume 36, pp. 238-246. https://doi.org/10.1016/j.tourman.2012.12.012

Ting, K., Ru-liang, K., \& Xiao-juan, M. (2011). Research on Service Quality Engineering Management of Tourist Destination. Systems Engineering Procedia, Volume 1., 309-316. https://doi.org/10.1016/j.sepro.2011.08.047

Yang, W.-C., Wang, C.-C., Huang, H.-C., \& Chang, C.-M. (2010). A Service Quality Contingency Model Approach to the Willingness of Revisit A Leisure Farm The Journal of International Management Studies, Volume 5, Number 2. 


\section{Annex}

\section{Questionnaire}

Answer all the statements in this questionnaire by providing an assessment of the extent to which the statement fits the reality. Fill in a box with a number with a value of 1-10 in the box provided and answer it on the bottom line.

A. Variable Quality of Service

1. The Zoo has good equipment facilities

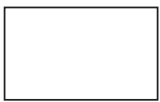

What equipment is not good at the zoo

2. The zoo employees provide good service

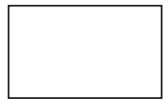

What aspects do you think are lacking in the service?

3. Employee of the zoo provide services quickly

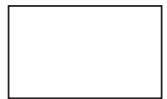

What services are needed to be fixed?

4. You feel safe visiting the zoo

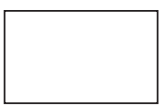

What kind of security do you need?

5. The zoo employee gives smile and greetings

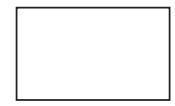


What smile and greetings do you expect?

B. Variable of Zoo Image

1. Zoo image compared to other Zoos

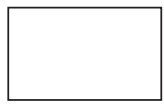

What is the zoo's position compared to other zoos?

2. The zoo Image in the eyes of your family and relatives.

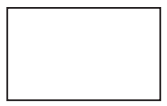

What is your family and relatives' opinion of the zoo?

3. Gembira Loka has a satisfactory service image

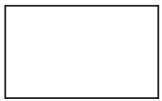

What kind of service satisfies you?

C. Variable of Visitor Satisfaction

1. I feel happy to visit Gembira Loka

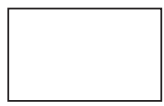

Happy like what you feel?

2. I feel satisfied to visit the zoo

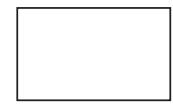


What facilities have not satisfied you?

3. I feel the zoo as expected

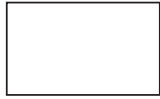

What facilities are in line with your expectations?

D. Variable of Revisited Intention

1. I will return to the zoo

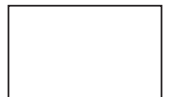

When will your plan return?

2. I want to feel the atmosphere of the zoo again

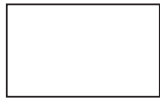

What atmosphere do you want to feel again?

3. The zoo worth to visit again

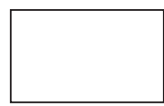

What factors make the zoo to be worth a visit again? 